2003

\title{
Beyond Dusky and Godinez: Competency Before and After Trial
}

Michael L. Perlin

New York Law School, michael.perlin@nyls.edu

Follow this and additional works at: https://digitalcommons.nyls.edu/fac_articles_chapters

Part of the Disability Law Commons, and the Law and Psychology Commons

\section{Recommended Citation}

Perlin, Michael L., "Beyond Dusky and Godinez: Competency Before and After Trial" (2003). Articles \& Chapters. 1276.

https://digitalcommons.nyls.edu/fac_articles_chapters/1276 


\title{
Beyond Dusky and Godinez: Competency Before and After Trial
}

\author{
Michael L. Perlin, J.D.*
}

Scholars have carefully considered all aspects of the incompetency to stand trial process, questions involving incompetency to confess, questions involving incompetency to be executed, and, to a lesser extent, questions related to incompetency to plead guilty or to waive counsel, but little attention has been paid to the relationship between incompetency and the full range of other criminal procedure issues: sentencing, appeals, consent to searches, and others. This article discusses this range of issues, assesses the factors relied upon by courts in deciding these cases and attempts to offer an agenda for future scholarly developments in this area. Copyright (C) 2003 John Wiley \& Sons, Ltd.

Even though the insanity defense is the media darling, the lightning rod of media ire, and topic of obsessive public preoccupation, ${ }^{1}$ researchers, scholars and practicing lawyers all agree that questions of criminal competency are, numerically, at least, far more important to the administration of criminal justice. ${ }^{2}$ For a variety of reasons the fact that incompetency determinations are usually done quietly and with little fanfare, the fact that incompetency defendants are usually significantly more disabled than insanity defendants and are thus less likely to have committed the kind of high-visibility crimes that make tabloid headlines, the fact that there is rarely any testimony about the actual crime at the incompetency hearing, ${ }^{3}$ the fact that the raising of the incompetency status is in no way a concession of having committed

\footnotetext{
*Correspondence to: Michael L. Perlin, J.D., Professor of Law, New York Law School, 57 Worth Street, New York, NY 10013, U.S.A. E-mail: mperlin@nyls.edu

${ }^{1}$ See, e.g., Alan Stone, Mental Health and Law: A System in Transition 41 (1975) ("The insanity defense is a pimple on the nose of justice but the patient is dying of congestive heart failure").

${ }^{2}$ On the frequency of competency evaluations, see, e.g., Gary Melton et al., Psychological EvaluaTIONS FOR THE COURTS $\S 6.05$ (a), at 135-136 (2nd ed. 1999) (evaluations have "increased significantly" since 1978, when they numbered 20,000); compare 4 Michael L. Perlin, Mental Disability Law: Civil and Criminal $\$ 9$ C-3.1, at $331 \mathrm{n} .37$ (2nd ed. 2002) (in New Jersey in 1982, insanity pleas entered in 50 of 32,500 felony cases).

${ }^{3}$ See 4 Perlin, supra note 2 , § 8A-3.2, at 38-39.
} 
the underlying criminal act ${ }^{4}$ - competency questions have never registered on our various radar screens with the same urgency and immediacy as have insanity defense questions. And this notwithstanding the fact that the U.S. Supreme Court has considered aspects of this question at least six times in the past three decades. ${ }^{5}$

This is important for two reasons: to reinforce the reality that criminal incompetency is a severely underconsidered issue (and this is territory that has been covered previously, ${ }^{6}$ and needs no further elaboration here), and that even discussions about "criminal incompetency" often ignore many of the critical competency questions that arise regularly - and with little fanfare-before the courts. ${ }^{7}$ And that is the subject of this article.

Self-evidently, the greatest focus is on, and will always be on, the seminal issue of incompetency to stand trial (IST): the substantive standards, $^{8}$ the procedural contours of the IST hearing, ${ }^{9}$ the means by which the state can treat the defendant so as to "make him" competent, ${ }^{10}$ and the procedures by which defendants found IST are institutionalized and released. ${ }^{11}$ Each of these has been the topic of Supreme Court attention and extensive scholarly commentary, ${ }^{12}$ and the question of restoration to competency (or "creation" of competency) by means of the involuntary administration of antipsychotic medications continues to be one of

\footnotetext{
"See Michael L. Perlin, "For the Misdemeanor Outlaw": The Impact of the ADA on the Institutionalization of Criminal Defendants with Mental Disabilities, 52 ALA. L. REV. 193, 206-207 (2000) ("Also disturbing is the often unstated but lingering assumption that any defendant on whose "behalf the incompetency status is raised is, in fact, "factually guilty" of the underlying crime. When I was a public defender, I represented in individual cases well over 200 criminal defendants who had been found - at some point - incompetent to stand trial. In not a single case did the prosecutor, the judge, or the forensic evaluator even acknowledge the possibility that the defendant might have been 'factually innocent' of the underlying charge").

${ }^{5}$ See, e.g., Fackson v. Indiana, 406 U.S. 715 (1972) (Due process applies to post-incompetency commitment process); Medina v. Califormia, 505 U.S. 437 (1992) (placing burden of proof on defendant at commitment hearing not unconstitutional); Cooperv. Oklahoma, 517 U.S. 348 (1996) (placing burden of proof on defendant at commitment hearing by quantum of clear and convincing evidence unconstitutional); Colorado v. Connelly, 479 U.S. 157 (1986) (Absent police coercion, mental disability alone will not invalidate confession); Ford v. Wainwright, 477 U.S. 399 (1986) (unconstitutional to execute a currently incompetent defendant); Godinez v. Moran, 509 U.S. 389 (1993) (unitary standard to be used in competency to stand trial, waive counsel, and plead guilty cases).

${ }^{6}$ See, generally, Michael L. Perlin, Pretexts and Mental Disability Law: The Case of Competency, 47 U. MIAMI L. REV. 625, 669-670 (1993); Bruce J. Winick, Restructuring Competency to Stand Trial, 32 UCLA L. REV. 921,940 (1985).

${ }^{7}$ There has been virtually no attention paid to another important issue: the extent to which the specific inquiry mandated by Dusky v. United States, 362 U.S. 402 (1960) (whether a defendant "has sufficient present ability to consult with his lawyer with a reasonable degree of rational understanding-and whether he has a rational as well as a factual understanding of the proceedings against him"), must be modified in determining competency in other contexts. This will be explored separately in a subsequent article.

${ }^{8}$ See Dusky, supra.

${ }^{9}$ See Pate v. Robinson, 383 U.S. 375 (1966); Drope v. Missouri, 420 U.S. 162 (1975); Medina, supra; Cooper, supra.

${ }^{10}$ Compare, e.g., United States v. Charters, 829 F. 2 d 479 (4th Cir. 1987), with United States v. Charters, 863

F. 2d 302 (4th Cir. 1988), cert. den., 494 U.S. 1016 (1990).

11 fackson, supra.

${ }^{12}$ See, e.g., 4 Perlin, supra note $2, \S \S 8 \mathrm{~A}-2$ to $8 \mathrm{~A}-5.6 \mathrm{~b}$, at $2-83$.
}

There has also been extensive behavioral commentary on competency standards and on the substance of competency evaluations See id., $\S 8 \mathrm{~A}-2.2$ at 10-12 n. 56 (citing sources). 
the "hottest" and most contentious issues in all mental disability law, and one on which the Supreme Court has just granted certiorari. ${ }^{13}$

But, again, these are not the only criminal competency issues to which attention has been paid. The Supreme Court has considered, variously, (i) the relationship between mental disability and the validity of a confession, ${ }^{14}$ (ii) the competency standards to be employed when a criminal defendant wishes to waive counsel or plead guilty, ${ }^{15}$ and (iii) the constitutionality of executing a once-competent-to-betried-but-now-incompetent criminal defendant, ${ }^{16}$ and each of these areas has spawned a generation of interpretive caselaw and critical literature. ${ }^{17}$

This is not to say that this entire area of the law is facially incoherent. ${ }^{18}$ Certainly, the Supreme Court's decision in Godinez v. Moran, holding that a unitary competency standard applies to questions of competency to stand trial, competency to plead guilty, and competency to waive counsel ${ }^{19}$ appeared to bring a measure of coherence-albeit misguided coherence ${ }^{20}$ - to this entire enterprise.

Yet, this is only one very small piece of the story. There are many other questions of "criminal competency" that have been the topic of dozens of court decisions, yet are nearly totally bereft of scholarly or clinical- or practitioner-based analysis. ${ }^{21}$ Nor does it appear that they lend themselves to any overarching theoretical construct. This article will identify and categorize these decisions, discussing briefly the current caselaw, and speculating as to why so little attention has been paid (and why that lack of attention is seriously problematic).

Importantly, Justice Kennedy's concurrence in Godinez focuses on one of the issues considered in this article: the impact of Godinez's unitary standard on cases involving other aspects of the criminal competency inquiry. Writing for himself and for Justice Scalia, Justice Kennedy asserted "The Due Process Clause does not mandate different standards of competency at various stages of or for different decisions made during the criminal proceedings." 22 Although he did not further define "criminal proceedings," this immediately followed his interpretation of the universality of the Dusky standard in "other" competency cases: "That

\footnotetext{
${ }^{13}$ See United States v. Sell, 282 F.3d 560 (8th Cir. 2002) (government could, subject to limitations, forcibly administer antipsychotic medication for the sole purpose of rendering pre-trial detainee competent to stand trial, where its interest in restoring defendant's competency so he could be brought to trial was paramount and no less intrusive means of restoring defendant's competency were available), cert. granted, 123 S. Ct. 512 (2002).

${ }^{14}$ Comelly, supra.

${ }^{15}$ Godinez, supra.

${ }^{16}$ Ford, supra. See also Penry v. Lynaugh, 492 U.S. 302 (1989); Atkins v. Virginia, 122 S. Ct. 2242 (2002).

${ }^{17}$ See, e.g., 4 PerLin, supra note 2 , $\S 8 \mathrm{~B}-2$ to $8 \mathrm{~B}-3.1 \mathrm{c}, \S \S 10-3.3$ to $10-3.3 \mathrm{~d}, \S \S 12-4.1$ to $12-4.2$, at $101-$ $117,406-421$, and 519-550.

${ }^{18}$ On the incoherence of insanity defense jurisprudence see, inter alia, Perlin, supra note 4, at 208, Michael L. Perlin, "The Borderline Which Separated You from Me": The Insanity Defense, the Authoritarian Spirit, the Fear of Faking, and the Culture of Punishment, 82 Iowa L. Rev. 1375, 1424 (1997), and Michael L. Perlin, Unpacking the Myths: The Symbolism Mythology of Insanity Defense furisprudence, 40 CASE W. REs. L. REv. $599,601(1989-90)$.

${ }^{19}$ Godinez, 509 U.S., at 390.

${ }^{20}$ See Michael L. Perlin, "Dignity Was the First to Leave": Godinez v. Moran, Colin Ferguson, and the Trial of Mentally Disabled Criminal Defendants, 14 BeHav. Scr. \& L. 61, 78 (1996) ("The Court's holding in Godinez reflected at its base its profound disinterest in (and perhaps, cynicism about) the integrity of the criminal trial process"), and $i d$. at 81 ("Godinez is, at base, a cynical and meretricious decision").

${ }^{21}$ This, of course, excludes the question of competence to be executed, a topic with a rich literature. See, e.g., 4 Perlin, supra note 2, $\$ 12-4.1 \mathrm{~d}$ at $539 \mathrm{n} .431$ (citing articles).

${ }^{22}$ Godinez, 509 U.S. at 404 (Kennedy, J., concurring) (emphasis added).
} 
standard is applicable from the time of arraignment through the return of a verdict.",23

\section{OTHER CRIMINAL COMPETENCIES ${ }^{24}$}

If the topics already discussed are to be excluded, the remaining areas of criminal competency (in which there has been some case law developed) can be divided into these groupings: pre-trial process issues, trial process issues, post-trial process issues, and others. It must be kept in mind that each of the pre-trial process issues precedes the "time of arraignment" referred to by Justice Kennedy in his Godinez concurrence, and each of the post-trial process issues follows the "time of verdict" in the same opinion. ${ }^{25}$

\section{Pre-Trial Process Issues}

\section{Confession Law}

There is a robust body of caselaw dealing with confession questions. Since 1960, it has appeared clear that a confession is inadmissible if the defendant was mentally incompetent at the time it was given. ${ }^{26}$ Since the U.S. Supreme Court's decision in Miranda v. Arizona, ${ }^{27}$ the prosecution has been prohibited from using any custodial statements unless the defendant has waived his right to silence by a voluntary, knowing, and intelligent waiver. ${ }^{28}$ Whether a waiver is knowingly and intelligently made depends on the specific facts and circumstances of each case, including the background, experience, and conduct of the accused; ${ }^{29}$ the state must bear the burden of proving that the waiver was so knowingly and intelligently made. ${ }^{30}$

Courts must employ "special care" in the evaluation of confessions of individuals with mental disabilities, ${ }^{31}$ and, while mental deficiency "of itself" 32 does not render a confession involuntary, it is a "relevant factor" 33 that must be considered in the "totality of circumstances.", Neither subnormal intelligence," "lack of education and illiteracy," 36 nor "previous incidents of mental instability" 37 are

\footnotetext{
${ }^{23} I d$, at 403 .

${ }^{24}$ This section is largely adopted from 4 Perlin, supra, note 2 , $\$ 8$ B-3.2 to 8B-3.5, at $117-128$.

${ }^{25}$ Godinez, 509 U.S., at 403.

${ }^{26}$ See Blackburn v. Alabama, 361 U.S. 199 (1960). Such a confession is proscribed as not being the product of "a rational intellect and free will." Id., at 208. See, e.g., Kimbell v. State, 252 Ga. 65, 311 S.E.2d 465 (1984).

But see Connelly, supra (coercive police activity a necessary predicate to finding of involuntariness of confession, even in the case of defendant with mental disabilities).

27384 U.S. 436 (1966).

${ }^{28} I d$., at 444 .

${ }^{29}$ Edwards v. Arizona, 451 U.S. 477 (1981). Cf. Connelly, supra.

${ }^{30}$ Miranda, 384 U.S., at 436.

${ }^{31}$ See, e.g., People v. Simmons, 326 N.E.2d 383 (III. 1975); People v. Turner, 306 N.E.2d 27 (III. 1973).

${ }^{32}$ People v. Redmon, 468 N.E.2d 1310, 1314 (III. App. 1984) (quoting Turner, 306 N.E.2d, at 30 ).

${ }^{33}$ See State v. Smith, 370 N.W.2d 827, 830 (Wis. 1985).

${ }^{34}$ Redmon, 468 N.E.2d at 1315 (quoting Tumer, 306 N.E.2d at 30). Cf. Connelly, 479 U.S. at 169-170 (notions of "free will" have no place in Constitutional analysis of confession's admissibility).

${ }^{35}$ See State v. Fenkins, 268 S.E.2d 458 (N.C. 1980).

${ }^{36}$ State v. Osborne, 330 S.E. 2 d 447, 448 (Ga. App. 1985).

${ }^{37}$ See State v. Vickers, 291 S.E.2d 599 (N.C. 1982).
} 
"necessarily dispositive" of the issue of mental competence at the time the confession is given. ${ }^{38}$

Generally, a statement has been found to be inadmissible where "the mental subnormality [sic] is so great that an accused is incapable of understanding the meaning and effect of his confessions," 39 or where defendant's mental illness is combined with other circumstances so that it is not the "product of an essentially free and unconstrained choice by the maker." 40

However, this is "old news." Other important pre-trial questions have been the subject of virtually no scholarly attention: matters involving searches and seizures, lineups, and preliminary hearings. Generally, with respect to these and other pretrial process rights, courts have declined to establish a separate standard for determining the competency of a criminal defendant to participate at a suppression hearing, generally ruling that the "bona fide doubt" procedural standard of Pate $v$. Robinson is similarly applicable. ${ }^{41}$

\title{
Search and Seizure
}

At least two cases have explored the relationship between competency to consent and a subsequent police search and seizure. ${ }^{42}$ In one, a federal district court ruled that mental competency is relevant to any inquiry in determining voluntariness of a consent. ${ }^{43}$ In the other, the Fourth Circuit rejected a defendant's similar argument, on the basis that the defendant cited "no authority for the proposition that such incompetency renders consent to the search invalid." 44 Also, a New York trial court has ruled that defense counsel was not entitled to waive an incompetent defendant's right to be present at a suppression hearing. ${ }^{45}$ Note, however, that all of these cases were decided prior to Godinez.

\footnotetext{
${ }^{38}$ State v. Simpson, 334 S.E.2d 53, 59 (N.C. 1985). Cf. State v. Sergent, 621 P.2d 209, $211-212$ (Wash. App. 1980) ("The combination of the defendant's incompetency, his mental illness, the medication he was taking, and his adverse reactions to those drugs, his attempt at plea bargaining and his waiver of fundamental constitutional rights without the assistance of his attorney, compel us to find that his statement to [the police officer] was involuntary").

${ }^{39}$ Casias v. State, 452 S.W.2d 483, 488 (Tex. Crim. App. 1970).

40 Fackson v. United States, 404 A.2d 911, 923 (D.C. App. 1979) (quoting Culombe v. Connecticut, 367 U.S. 568, 602 (1961)).

${ }^{41}$ United States ex rel. Phillips v. Lane, 580 F. Supp. 839, 843 (N.D. Ill. 1984) (citing cases). See also Peoplev. Vallen, 488 N.Y.S.2d 994, 997 (Sup. Ct. 1985) ("The criminal process does not proceed in ... piecemeal and independent stages, but... all stages of a criminal proceeding are interdependent and intertwined").

${ }^{42}$ On a defendant's competency to consent to a police search, see James Wulach, Psychological Evaluation of the Consent to Search, 18 J. Psychiatry \& L. 319 (1990).

On the role of consent in the area of search and seizure law in this context generally, see Russell Galloway, Basic Fourth Amendment Analysis, 32 SANTA Clara L. Rev. 737, 760-761 (1992), citing in part Schneckloth v. Bustamonte, 412 U.S. 218 (1973):
}

\begin{abstract}
Searches are permitted without probable cause or particularized justification if based on voluntary consent of a person with authority over the place searched or a person whom the police reasonably believe possesses such authority. To determine whether consent is voluntary, the Court uses a "totality of the circumstances" test focusing on such factors as the competence and mental condition of the person who consented, whether she knew of the right to refuse, whether she cooperated or resisted, whether she was in custody when she consented, and whether the police made a "claim of authority" to search or engaged in other coercive conduct.
\end{abstract}

\footnotetext{
${ }^{43}$ United States v. Ocampo, 492 F. Supp. 1211 (E.D.N.Y. 1980).

${ }^{44}$ United States v. Flannery, 879 F.2d 8631989 WL 79731 , *4 (4th Cir. 1989).

${ }^{45}$ See People v. Matthews, 585 N.Y.S.2d 948 (Sup. Ct. 1992).
} 


\section{Lineups}

One case has held that an incompetent criminal suspect could be required to participate in a pre-arraignment lineup. ${ }^{46}$ The court in this case cited Justice Kennedy's Godinez concurrence and concluded that it was "unclear" whether the Dusky standard applied to pre-arraignment matters. ${ }^{47}$

\section{Preliminary Hearing}

One case has held that if an information ${ }^{48}$ is dismissed due to defendant's incompetence at the preliminary hearing stage, the defendant is entitled to another preliminary hearing once competence is restored. ${ }^{49}$ Godinez was not cited in this case.

\section{Trial Process Issues}

Other cases have considered the relationship between a defendant's competency and such issues as jury waiver, evidentiary objections, and statements to the media. Yet others have considered the implications of juror incompetency and witness incompetency. ${ }^{50}$

In a related context, other courts have considered the interplay between incompetency and the entry of pleas of not guilty by reason of insanity and pleas of guilty but mentally ill.

\section{Fury Waivers}

Courts have split on jury waiver questions. The Ninth Circuit has ruled that a waiver should not have been accepted without further inquiry as to defendant's mental state ${ }^{51}$ noting that the defendant "must be competent to waive the jury right, and the waiver must in fact be voluntary, knowing, and intelligent." 52 According to the Ninth Circuit, this requirement of Godinez spoke to more than simply a competency determination:

Whereas competency goes to a defendant's capacity in general, " $[t]$ he purpose of the 'knowing and voluntary' inquiry, by contrast, is to determine whether the defendant actually does understand the significance and consequences of a particular decision." The Court has called this inquiry a "serious and weighty responsibility." fohnson $v$. Zerbst, 304 U.S. 458, 465...(1938). We now hold that district courts may not discharge this responsibility in cases where they have reason to suspect a defendant may suffer from mental or emotional instability without an in-depth colloquy which reasonably assures the court that under the particular facts of the case, the signed waiver was voluntarily, knowingly, and intelligently made. ${ }^{53}$

On the other hand, another court has ruled that a defendant's due process rights were not violated when jury selection proceeded while defendant was undergoing psychological evaluation for purposes of determining competency to stand trial, a

\footnotetext{
${ }^{46}$ See Matter of Harris, 627 N.Y.S. 2d 207 (Sup. Ct. 1995), and see $i d$. at 209-211 (explaining the significance of this inquiry).

${ }^{47} I d$., at 209.

${ }^{48}$ California has long proceeded in criminal cases by the use of an "information" rather than an indictment. See Hurtado v. California, 110 U.S. 516 (1884).

${ }^{49}$ People v. Duncan, 93 Cal. Rptr. 2d 173 (App. 2000), reh'g denied (2000).

${ }^{50}$ Of course, Godinez is not facially relevant to either of these issues.

${ }^{51}$ United States v. Christensen, 18 F.3d 822 (9th Cir. 1994).

${ }^{52}$ Id., at 824, citing Godinez, 509 U.S., at 399-400.

${ }^{53} \mathrm{Id}$., at 826 , also citing Godinez, 509 U.S., at $401 \mathrm{n} .12$.
} 
case in which no finding of incompetency had ever been made. ${ }^{54}$ In addition, one pre-Godinez court has required a separate finding that a defendant-found to be competent to stand trial — was also competent to waive a jury trial. ${ }^{55}$

\section{Evidentiary Objections}

On the question of the impact of a defendant's incompetence on the admissibility into evidence of several letters he wrote at the time he had been found incompetent to stand trial, a Virginia appellate court has ruled that such incompetence did not preclude admission into evidence. ${ }^{56}$ Another court has ruled, contrarily, that it was reversible error to use the deposition testimony of the victim in a criminal case that was taken at the time when the defendant was incompetent. ${ }^{57}$

\section{Statements to the Media}

Yet another court has concluded that finding defendant incompetent to stand trial compelled the conclusion that he was also incompetent to waive other rights relating to the prosecution (in this case, speaking publicly to the media about the alleged crime).$^{58}$

$$
\text { Competency of furors }{ }^{59}
$$

At least one court has ruled that there was no error requiring reversal of a conviction where a juror related his "reactive psychosis" experience to other jurors. ${ }^{60}$ Here, the court reasoned:

While jurors may not receive information from an outside source nor act as expert witnesses in the jury room, they are entitled to rely on and to relate their own common sense and life experiences during deliberations. Here the record reveals only the statement quoted above without any indication that the jury was improperly pressured to apply this juror's personal experience to the case at hand. ${ }^{61}$

\section{Competency of Witness to Testify ${ }^{62}$}

Many cases have considered the procedures to be employed in determining whether a witness is competent to testify. The lead case of Sinclair $v$. Wainwright ${ }^{63}$ set out the controlling legal standards:

\footnotetext{
${ }^{54}$ Brown v. Doe, 803 F. Supp. 932 (S.D.N.Y. 1992), aff'd, 2 F.3d 1236 (2d Cir. 1993), cert. denied, 510 U.S. 1125 (1994).

${ }^{55}$ State v. Cameron, 704 P.2d 1355 (Ariz. 1985); see also Coronado v. Lefevre, 748 F. Supp. 131 (S.D.N.Y. 1990) (same standard to determine competency to waive jury trial as competency to stand trial); compare Harringer v. State, 566 So. 2d 893 (Fla. Dist. Ct. App. 1990) (no evidence presented that defendant was competent to waive jury trial).

${ }^{56}$ See fones v. Commonwealth, 526 S.E.2d 281 (Va. App. 2000).

${ }^{57}$ Williams v. State, 685 N.E.2d 730 (Ind. App. 1997).

${ }^{58}$ Mann v. State's Attomey for Montgomery County, 468 A.2d 124, 129 (Md. 1983).

${ }^{59}$ Although this and the following subsection (competence of a witness to testify) raise different issues than the questions posed in the remainder of this article, they are included here because the overarching questions of competency are frequently assessed by courts in the same ways.

${ }^{60}$ See State v. Lindeken, 799 P.2d 23 (Ariz. App.), review denied (1990).

${ }^{61} \mathrm{Id}$., at 406 (defendant convicted of manslaughter; insanity defense rejected).

${ }^{62}$ See supra note 59.

${ }^{63} 814$ F.2d 1516 (11th Cir. 1987).
} 
Turning then to the merits of appellant's due process claim, it may be noted "that a [person with mental disability] may be allowed to testify if he is able to [comprehend] the obligation of an oath and give a correct account of matters he has seen or heard ..." (Shuler v. Wainwright, 491 F.2d 1213 (fifth Cir.1974)). But if a patient in a mental institution is offered as a witness, an opposing party may challenge competency, whereupon it becomes the duty of the court to make such an examination as will satisfy the court of the competency of the proposed witness. (Id. at 1223-24). And if the challenged testimony is crucial, critical or highly significant, failure to conduct an appropriate competency hearing implicates due process concerns of fundamental fairness [citation omitted].

This is not to say "that every allusion as to incompetency of a witness [is to] be exhaustively explored by the trial judge, particularly where all other evidence substantiates competency." United States v. Crosby, 462 F.2d 1201, 1203 n. 5 (D.C. Cir.1972). But in the present situation, as in Crosby, $i d$. at 1203, we believe a "red flag" of material impact on competency was flying. [The potential witness] was offered as an eyewitness to many of the critical aspects of the state's case against Sinclair. He had been declared incompetent to stand trial by the judge who was trying Sinclair. Only by a reasonable exploration of all the facts and circumstances could the trial judge exercise sound discretion concerning the competency of the witness and the findings of the court with respect to competency should have been made to appear on the record. The record reflects no searching exploration and no stated reasons for overruling appellant's competency objections.

In such circumstances, we are obliged to remand for a determination on the record of the competency of the witness... ${ }^{64}$

At least one of Sinclair's assertions - its reliance on Shuler for the proposition that "If a patient in a mental institution is offered as a witness, an opposing party may

${ }^{64}$ Id., at $1522-1523$.

For earlier case law, see Shuler v. Wainwright, 491 F.2d 1213 (5th Cir. 1974); Hills v. Henderson, 529 F.2d 397 (5th Cir.), cert. denied, 429 U.S. 850 (1976); United States v. Crosby, 462 F.2d 1201 (D.C. Cir. 1972).

For later cases, see, e.g., Hughes v. State, 546 N.E.2d 1203 (Ind. 1989); Ambles v. State, 383 S.E.2d 555 (Ga. 1989); Commonwealth v. Fayerweather, 546 N.E.2d 345 (Mass. 1989); State v. Dumaine, 783 P.2d 1184 (Ariz. 1989); Gilpin v. McCormick, 921 F.2d 928 (9th Cir. 1990); Nelson v. Farrey, 874 F.2d 1222 (7th Cir. 1989), cert. denied, 493 U.S. 1042 (1990); Statev. Olivo, 589 A.2d 597 (N.J. 1991); United States v. Pryce, 938 F.2d 1343 (D.C. Cir. 1991); State in Interest of B.G., 589 A.2d 637 (App. Div. 1991); People v. Rainge, 570 N.E.2d 431, reh'h denied (III. App. 1991); Simmons v. State, 683 So. 2 d 1101 (Fla. Dist. App. 1996), reh'g denied (1997); State v. Blasius, 559 A.2d 1116 (Conn. 1989); State v. Danforth, 573 N.W.2d 369 (Minn. App. 1997), review denied (1998), appeal after remand, 1999 WL 262143 (1999); Gilstrap v. State, 945 S.W.2d 192 (Tex. App. 1997), petit. for discretionary review denied (1997); State v. Henries, 704 A.2d 24 (App. Div. 1997); Schutz v. State, 957 S.W.2d 52 (Tex. Crim. App. 1997); Commonwealth v. Lloyd, 702 N.E.2d 395 (Mass. App. Ct. 1998); State v. Ballos, 602 N.W.2d 117 (Wis. App. 1999), review denied, 609 N.W.2d 473 (Wis. 2000); State v. Dillon, 1999 WL 148370 (Ohio App. 1999); State v. Washington, 506 S.E.2d 283 (N.C. App. 1998), review denied (1999), appeal dismissed (1999); United States v. Gonzalez-Maldonado, 115 F.3d 9 (1st Cir. 1997); People v. Stephenson, 555 N.E.2d 802 (III. App. 1990).

On whether the prosecution must disclose the medical record of a government witness, see Drew $v$. United States, 46 F.3d 823 (8th Cir. 1995), cert. denied, 516 U.S. 817 (1995) (failure to disclose was immaterial; no due process deprivation).

On the question of the state's obligation to turn over witness statements at competency hearings, see People v. McPhee, 614 N.Y.S.2d 884 (Sup. 1994) (state compelled to turn over statements); State v. Bruno, 673 A.2d 1117 (Conn. 1996) (trial court properly denied defendant's motion for in camera inspection of witnesses' psychiatric records); cf. State v. Israel, 963 P.2d 897 (Wash. App. 1998), review denied, 972 P.2d 465 (Wash. 1998) (no compelling reasons to justify psychological examination of alleged co-conspirator).

See generally Note, The Mentally Deficient Witness: The Death of Incompetency, 14 Law \& Psychol. Rev. 107 (1990). 
challenge competency, whereupon it becomes the duty of the court to make such an examination as will satisfy the court of the competency of the proposed witness" 65 - is seriously flawed. As a matter of law, incompetency cannot be presumed as a result of either mental illness or institutionalization. ${ }^{66}$ Furthermore, there is "no necessary relationship between mental illness and incompetency which renders [mentally ill persons] unable to provide informed consent to medical treatment." $" 67$ Yet, it is clear that courts will continue to, sub silentio, follow this doctrine, especially in criminal cases.

\section{Impact of Incompetency Finding on Ability to Enter Insanity Plea ${ }^{68}$}

Several cases have considered the significance of an incompetency finding on a defendant's ability to enter a plea of not guilty by reason of insanity, holding that due process prohibits any determination of sanity until such time as the defendant is restored to competency. ${ }^{69}$ Another case has held that a statute permitting an incompetent defendant to offer a defense on the merits, but not one based on mental illness, did not violate the defendant's equal protection rights. ${ }^{70}$ As an incompetent defendant is definitionally unable to participate in his defense, it could not be assured that any adjudication resulting from an insanity trial would "represent a fair and just determination of the mental element of the offense placed in issue by the insanity plea." 71

On the other hand, the fact that a defendant had previously been found to be insane does not render him subsequently incompetent to proceed to trial per se on another charge. ${ }^{72}$ Yet another case has found that a defendant who elects to represent himself at trial can also waive pleading the insanity defense. ${ }^{73}$ Interestingly, in this case, the Utah Supreme Court used Godinez to find for the defendant:

\footnotetext{
${ }^{65}$ Sinclair, 514 F.2d, at 1522, quoting Shuler, 491 F.2d, at 1223-1224.

${ }^{66}$ In re Labelle, 728 P.2d 138, 146 (Wash. 1986).

${ }^{67}$ Davis v. Hubbard, 506 F. Supp. 915, 935 (N.D. Ohio 1980); Michael L. Perlin, Competency, Deinstitutionalization and Homelessness: $A$ Story of Marginalization, 28 Hous. L. REv. 63, 113-114 (1991); Bruce J. Winick, Competency to Consent to Treatment: The Distinction Between Assent and Objection, 28 Hous. L. Rev. 15 (1991).

${ }^{68}$ For a clinical perspective, see William Johnson et al., The Relationship of Competency to Stand Trial and Criminal Responsibility, 17 Crim. Just. \& BeHAv. 169 (1990).

${ }^{69}$ See Coolbroth v. District Ct. of 17 th Fudicial Dist., 766 P.2d 670 (Colo. 1988); United States v. Evans, 704 F. Supp. 81 (E.D. Pa. 1989); see also State v. Werner, 796 P.2d 610 (N.M. 1990), cert. den. (1990). Compare People v. Angeletakis, 7 Cal. Rptr.2d 377, review denied (Cal. App. 1992), cert. denied, 507 U.S. 926 (1993) (affirming denial of motion of insanity acquittee for proceedings to consider his competency to stand trial on the question of an extension of his post-insanity acquittal commitment). Coolbroth is discussed in this context in Justine Dunlap, What's Competence Got to Do With It: The Right Not to Be Acquitted by Reason of Insanity, 50 OKLA. L. REv. 495, 506 n.89 (1997).

${ }^{70}$ Spero v. Commonwealth, 678 N.E.2d 435 (Mass. 1997).

${ }^{71}$ Coolbroth, 766 P.2d at 673. See also Evans, 704 F. Supp. at 84 ("futile" to attempt to conduct meaningful insanity evaluation as long as defendant remains "overtly psychotic"). See generally R.J. Mackay \& Gerry Kearns, The Trial of the Facts and Unfitness to Plead, 1997 Crim. L. REv. 644.

${ }^{72}$ People v. Blehm, 791 P.2d 1177, 1181 (Colo. Ct. App. 1989), aff', 817 P.2d 988 (Colo. 1991).

${ }^{73}$ State v. Woodland, 945 P.2d 665 (Utah 1997). On a defendant's right to not plead insanity, see 4 PerLIN, supra note $2, \S 9 \mathrm{~A}-8$, at $241-245$.

Compare State v. Martinez, 651 A.2d 1189 (R.I. 1994) (Standards for competency to stand trial and competency to testify as witness are distinct from standard for criminal responsibility).
} 
Therefore, Woodland should not be required to display a heightened level of competency to waive his right to a particular defense. See Godinez... (holding that competency standard for standing trial is same as standard for determining competency to waive right to counsel). The trial court correctly concluded that Woodland knowingly and voluntarily waived his right to assert a mental illness defense. ${ }^{74}$

\section{Impact of Incompetency Finding on Ability to Enter Guilty but Mentally Ill Plea}

At least one case has held that a guilty but mentally ill conviction ${ }^{75}$ would be invalid where the defendant's competence had not been re-evaluated before trial. $^{76}$

\section{Post-trial Process Issues}

Cases have considered the impact of competency on virtually every post-trial stage, including motions for new trials, sentencing, probation hearings, parole revocation hearings, conditional release hearings, participation in post-conviction relief proceedings, and appeals. ${ }^{77}$ Again, the application of the Godinez unitary standard to post-conviction proceedings has never been considered by the Supreme Court. ${ }^{78}$ This gap has been considered in Coe v. Bell, a Sixth Circuit death penalty case, in which the defendant argued that the common law standard governing the modern standard for competency to stand trial also applied to a competency-to-be-executed proceeding, citing to Godinez. ${ }^{79}$ The Sixth Circuit responded by citing to the language in Justice Kennedy's concurrence already discussed, adding:

It appears from his opinion, however, that Justice Kennedy was concerned that the same standard be applied from the time of a defendant's arraignment through his sentencing. ... Because competency to be executed involves different interests than competency to stand trial in the first instance, we do not believe that a state rigidly must apply the competency-to-stand-trial standard in this context where it does not make sense in modern practice. ${ }^{80}$

\section{New Trials}

At least one case has held that a defendant has a right to be competent at a motion for a new trial. ${ }^{81}$

\footnotetext{
${ }^{74}$ Woodland, 945 P.2d at $670-671$.

${ }^{75}$ See 4 Perlin, supra note $2, \S 9 \mathrm{~A}-3.7$, at $169-179$.

${ }^{76}$ See People v. Harris, 460 N.W.2d 239 (Mich. App. 1990).

${ }^{77}$ The discussion in this section omits consideration of these collateral issues in the death penalty context. See 4 Perlin, supra note $2, \S 8 \mathrm{~B}-3.4 \mathrm{~g}$, at 127 , for a specific study of these issues.

${ }^{78}$ Also, to the best of my knowledge, an issue discussed by the Supreme Court in Drope v. Missouri, 420 U.S. 162 (1975), has never been considered in this context: can the question of competency here be raised by the prosecutor or the judge, or simply by defense counsel? See Perlin, supra note 4, at $198 \mathrm{n} .33$ (discussing Drope in this context).

${ }^{79} 209$ F.3d 815, 826 (6th Cir. 2000), rehearing den. (6th Cir. 2000), cert. den., 529 U.S. 1084 (2000). ${ }^{80} \mathrm{Id}$.

${ }^{81}$ See Williams v. Turpin, 87 F.3d 1204 (11th Cir. 1996). Interestingly, neither Dusky nor Drope nor Godinez was cited in this case.
} 


\section{Sentencing}

It is black letter law that a court may not sentence an incompetent defendant. ${ }^{82}$ In the case of a defendant who becomes incompetent between the time of the guilty verdict and the time of sentence, most state statutes provide for the same test to be employed as is used when determining a defendant's competency to stand trial, ${ }^{83}$ with "the emphasis on the defendant's capacity to tell his attorney about factors that would mitigate his sentence or would refute aggravating circumstances brought up by the prosecution, as well as on his understanding of the punishment." ${ }^{\text {"84 }}$ Also, at least one court has held that a psychiatric competency evaluation cannot be ordered after a defendant is sentenced. ${ }^{85}$

\section{Probation Hearings}

Some attention is now being paid to the relationship between competency and probation revocation matters. ${ }^{86}$ If a reasonable doubt arises as to a defendant's

\footnotetext{
${ }^{82}$ See Bruce J. Winick \& Terry L. DeMeo, Competency to Stand Trial in Florida, 35 U. Miami L. Rev. 31,72 (1980). and cases cited at id. n.242.

See, e.g., United States v. Collins, 949 F.2d 921 (7th Cir. 1991); State v. Phelps, 600 N.E.2d 329 (Ohio App. 1991), jurisdictional motion overruled, 583 N.E.2d 971 (Ohio 1992); Stover v. State, 621 N.E.2d (Ind. App. 1993); Calloway v. State, 651 So. 2 d 752 (Fla. Dist. App. 1995); compare People v. Hall, 541 N.E.2d 1369, 1375-1376 (III. App. 1989) (defendant's "cognitive difficulties" did not raise bona fide doubt of fitness so as to entitle him to presentencing fitness examination); People v. Sanchez, 662 N.E.2d 1199 (III. 1996), reh'g denied (1996), cert. denied, 483 U.S. 1010 (1996) (no error where trial judge failed to conduct fitness hearing prior to sentencing hearing); State v. Lott, 671 So. $2 \mathrm{~d} 1182$ (La. App. 1996) (defendant competent at time of sentencing); see also Gilbert v. State, 951 P.2d 98 (Okla. Crim. App. 1997), reh'g denied (1998), post-conviction relief denied, 955 P.2d 727 (Okla. Crim. App.), cert. denied, 525 U.S. 890 (1998); People v. Dewer, 663 N.Y.S.2d 425 (A.D. 1997), appeal denied, 670 N.Y.S.2d 406 (1998); People v. Walker, 685 N.E.2d 997 (III. App. 1997); United States v. Hinton, 18 F.3d 910 (8th Cir. 2000); People v. Kilgore, 992 P.2d 661 (Colo. App. 1999), reh'g denied (1999), cert. denied (2000); State v. Tilden, 988 S.W.2d 568 (Mo. App. 1999); Reed v. Texas, 14 S.W.3d 438 (Tex. App. 2000), petit. for discretionary review refused (2001); State v. Fish, 759 So. 2 d 937 (La. App. 2000); Woods v. State, 994 S.W.2d 32 (Mo. App. 1999); United States v. Gigante, 1997 WL 782355 (E.D.N.Y. 1997), supplemented, 996 F. Supp. 194
} (E.D.N.Y. 1998) (defendant competent to be sentenced).

United States v. Sanchez, 38 F. Supp. 2d 355, 366 (D.N.J. 1999) has cited Godinez (using a "cf. also" reference) on the competency-to-be-sentenced question, on the "modest aim" of a competency inquiry: ("seek[ing] to ensure that [the defendant] had the capacity to understand the proceedings and to assist counsel").

On the relationship between a defendant's "episodes" at sentencing and his competency to stand trial, see Sandham, supra (competency hearing required).

${ }^{83}$ See Barbara Weiner, Mental Disability and the Law, in The Mentally Disabled and the Law 693, 705706 (S.J. Brakel et al. eds., 3d ed. 1985). See generally Weissman, Determinative Sentencing and Psychiatric Evidence: $A$ Due Process Examination, 27 ST. Louis U.L.J. 347 (1983).

${ }^{84}$ Weiner, supra note 83 at 706 . See, e.g., Wojtowicz v. United States, 550 F.2d 786 (2d Cir.), cert. denied, 431 U.S. 972 (1977) (defendant entitled to evidentiary hearing as to competency at time of sentencing as to his allegations he had attempted to commit suicide on eve of sentencing); Pate v. Commonzvealth, 769 S.W.2d 46 (Ky. 1989) (competency hearing not required); United States v. Pellerito, 878 F.2d 1535 (1st Cir. 1989), appeal after remand sub nom.; United States $v$. Rivera-Martinez, 931 F.2d 148, cert. denied, 502 U.S. 862 (1991) (examination required to determine competency at time of sentencing); State v. Drga, 916 P. 2 d 739 (Mont. 1996) (resumption of proceedings following commitment to mental health facility without determining that defendant had regained his fitness to stand trial invalidated conviction and sentence).

${ }^{85}$ State v. Tokar, 918 S.W.2d 753 (Mo. 1996), cert. den., 519 U.S. 933 (1996).

${ }^{86}$ See State v. Lockwood, 632 A.2d 655 (Vt. 1993) (no competency hearing required prior to commencement of probation revocation hearing); see also Merle v. United States, 683 A.2d 755 (D.C. 1996) (mental illness not a defense to probation violation); Guzman v. State, 923 S.W.2d 792 (Tex. App. 1996) (defendant competent at time of probation revocation hearing); compare State v. Singleton, 472 S.E. 2 d 640 (S.C. App. 1996) (Trial court abused its discretion in not ordering competency examination in probation revocation proceeding). 
competence to participate in a probation hearing, ${ }^{87}$ the court must hold a separate hearing to determine the defendant's competence to participate. ${ }^{88}$

\section{Parole Revocation Hearings}

Courts are beginning to consider the relationship between competency and parole revocation hearings; generally, it has been held that the court must hold a separate hearing to determine the defendant's competence to participate. ${ }^{89}$

\section{Conditional Release Hearings}

In cases involving conditional release or community supervision, the court must hold a separate hearing to determine the defendant's competence to participate. ${ }^{90}$

\section{Participation in Post-Conviction Relief Proceedings}

Courts have begun to consider the question of a defendant's competency to participate in post-conviction proceedings, ${ }^{91}$ and have generally found that the trial competency standards apply at this stage. ${ }^{92}$ In O'Rourke $v$. Endell, the court focused on that aspect of Godinez that discussed the standards for waiver, stressing that the purpose of the "knowing and voluntary" inquiry "is to determine whether the defendant actually does understand the significance and consequences of a particular decision and whether the decision is uncoerced."93 In Carter v. State, a death penalty case, the court underscored that competency hearings are required "only after a capital defendant shows there are specific factual matters at issue that require the defendant to independently consult with counsel.",94

\footnotetext{
${ }^{87}$ See, e.g., Sailer v. Gunn, 548 F.2d 271 , 274 (9th Cir. 1977); Soria v. State, 1997 WL 61491 (Tex. App. 1997); State ex rel. Vanderbeke v. Endicott, 563 N.W.2d 883 (Wis. 1997); State ex rel. Fuergens v. Cundiff, 939 S.W.2d 381 (Mo. 1997); Metzgar v. State, 741 So. 2 d 1181 (Fla. Dist. App. 1999). Godinez is cited in none of the post- 1993 cases in this cohort.

${ }^{88}$ See Winick \& DeMeo, supra note 82, at 73; compare State v. Qualls, 552 N.E.2d 957 (Ohio App. 1988) (Issue of competency to participate in probation revocation proceeding may be raised by court or defendant; decision as to whether to hold competency hearing vested in trial court's sound discretion).

${ }^{89}$ See Winick \& DeMeo, supra note 82 , at 73 ; compare Qualls, supra (Issue of competency to participate in probation revocation proceeding may be raised by court or defendant; decision as to whether to hold competency hearing vested in trial court's sound discretion), to People ex rel. Newcomb v. Metz, 409 N.Y.S.2d 554 (A.D. 1978) (Absent statutory authority to contrary, interests of fundamental fairness mandated a consideration of parolee's mental competency during parole revocation process; a determination of that question, however, is not a condition precedent to parole revocation proceeding, but merely a factor to be considered in mitigation of, or as an excuse for, charged violations of parole).

${ }^{90}$ United States v. Woods, 944 F. Supp. 778 (D. Minn. 1996) (conditional release); Rice v. State, 991 S.W.2d 953 (Tex. App. 1999), reh'g overruled (1999), petit. for discretionary review refused (1999) (community supervision). Godinez is cited in neither case.

${ }^{91}$ See State v. Debra A.E., 523 N.W.2d 727 (Wis. 1994) (setting out standards to be employed in cases in which the defendant is unable to assist counsel or to make decisions committed by law to defendant with reasonable degree of rational understanding).

${ }^{92}$ Carter v. State, 706 So. 2 d 873 (Fla. 1997), reh'g denied (1998); Sanchez-Velasco v. State, 702 So. 2 d 224 (Fla. 1997); O'Rourke v. Endell, 153 F.3d 560 (8th Cir. 1998), reh'g \& suggestion for reh'g en banc denied (8th Cir. 1998), cert. denied, 525 U.S. 1148 (1999); Matheney v. State, 688 N.E.2d 883 (Ind. 1997), reh'g denied (1998); People v. Fohnson, 730 N.E.2d 1107 (III. 2000); House v. State, 754 So. 2d 1147 (Miss. 1999), reh'g denied (2000); Hundley v. State, 1999 WL 668723 (Tenn. Crim. App. 1999).

${ }^{93}$ O'Rourke, 153 F.3d, at $567-568$.

${ }^{94}$ Carter, 706 So. $2 \mathrm{~d}$, at 875 .
} 


\title{
Appeals
}

At least one court has held that, if there is a bona fide question as to a defendant's competence, he does not waive his right to file an appeal. ${ }^{95}$ On the other hand, at least three state supreme courts have held that a defendant's appeal could proceed even if the defendant had become incompetent, as the appellate record contained only legal issues, and counsel did not need to rely on the defendant to determine which issues were worth pursuing. ${ }^{96}$

\section{Other Miscellaneous Procedural Matters}

Other cases have explored questions of a defendant's competence to be extradited, ${ }^{97}$ the impact of a defendant's incompetence on a sexually violent predator act (SVPA) commitment, ${ }^{98}$ and the application of Godinez to questions of waiver of counsel in the involuntary civil commitment hearing of a federal prisoner. ${ }^{99}$ In this last setting, the Eighth Circuit rejected the defendant's argument that his commitment to a mental health facility demonstrated his inability to waive counsel as "unpersuas[ive]":

\begin{abstract}
Whether an individual possesses sufficient capacity to knowingly waive his right to counsel is no longer distinct from the question of his competency to stand trial [citing to Godinez]. The mere fact that Veltman needed "custody for care or treatment in a suitable facility" does not mean he lacked sufficient capacity to decide to proceed pro se.... The purpose of the waiver doctrine "is to determine whether the defendant actually does understand the significance and consequences of a particular decision and whether the decision [to proceed unassisted] is uncoerced" [citing to Godinez]. After carefully reviewing the record, we affirm the district court's determination that Veltman possessed sufficient mental capacity to waive his statutory right to counsel ... . ${ }^{100}$
\end{abstract}

\section{CONCLUSION}

The lack of commentary about the cases in this important (yet largely hidden) area of the law is surprising. The failure of most of the cases to consider carefully the

\footnotetext{
${ }^{95}$ People v. McKay, 668 N.E.2d 580 (III. App. 1996), appeal denied, 675 N.E.2d 637 (III. 1996). See also Gentzen v. State, 689 So. 2d 1178 (Fla. Dist. App. 1997), reh'g denied (1997) (Court lacked jurisdiction to consider appeal filed by defendant who had been found to be incompetent to proceed in criminal case). Compare State v. Currier, 649 A.2d 246 (Vt. 1994) (dismissal of appeal inappropriate where record did not indicate whether waiver was knowing and intelligent).

${ }_{96}^{96}$ People v. Kelly, 822 P.2d 385, 413-415 (Cal. 1992), reh'g denied (1992), cert. denied, 506 U.S. 881 (1992); State v. White, 815 P.2d 869, 878 (Ariz. 1991); Dugar v. Whitley, 615 So. 2 d 1334 (La. 1993). ${ }^{97}$ In re Hinnant, 678 N.E.2d 1314 (Mass. 1997) (Defendant must be competent for rendition of extradition to proceed), discussed in Eric Loeffler, In re Hinnant: The Relevance of Competence in Interstate Extradition Proceedings, 25 New Eng. J. Crim. \& Civ. Confinement 469 (1999); Lopez-Smith v. Hood, 121 F.3d 1322 (9th Cir. 1997) (affirming denial of defendant's petition for writ of habeas corpus); Oliver v. Barrett, 269 Ga. 512, 500 S.E.2d 908 (1998) (extradition proper). See also, e.g., Pruett v. Barry, 696 P.2d 789 (Colo. 1985); fones v. Warmuth, 272 S.E.2d 446 (W. Va. 1980); People v. Kent, 507 N.Y.S.2d 353 (Sup. Ct. 1986).

${ }^{98}$ Commitment of Smith, 600 N.W.2d 258 (Wis. App. 1999) (Defendant has same right to be competent during SVPA proceedings as in any criminal proceeding); see generally 1 PERLIN, supra note $2, \S 2 \mathrm{~A}-3.3$, at 75-92.

${ }^{99}$ United States v. Veltman, 9 F.3d 718 (8th Cir. 1993), cert. denied, 511 U.S. 1044 (1994); see 1 PerLIN, supra note $2, \S 2 \mathrm{C}-4.2 \mathrm{a}$, at $317-318$.

${ }^{100}$ Veltman, 9 F. 3d, at 722 .
} 
relevant precedents (and analogous developments in other jurisdictions) is even more surprising. And this is, to some extent, curious, given the significance of this inquiry at every juncture of the criminal process.

There is no question that competency considerations at other stages of pretrial, trial, and post-trial proceedings will grow in importance in the coming years. Although Godinez established a unitary test for competency to plead guilty and to waive counsel, again, collateral competency questions permeate the entire criminal trial process. It is a matter to which closer attention must be paid.

\section{ACKNOWLEDGEMENT}

The author wishes to thank Betsy Fiedler for her excellent research assistance. 